\title{
JEJAK SEJARAH BUNG KARNO DI BENGKULU
}

\author{
Agus Setiyanto \\ Fakultas Ilmu Sosial dan Politik Universitas Bengkulu \\ Jl. Wr. Supratman, Kandang Limun Bengkulu \\ agussetiyanto@yahoo.com
}

\begin{abstract}
Even History of Bung Karno in Bengkulu. This writing aims to complete historical data about the journey of Bung Karno's struggle during his exile in Bengkulu. Writing the traces of Bung Karno's history in Bengkulu (1938-1942) besides being beneficial for the development of historical writing for the Indonesian nation, it is also expected to be useful as a historical education material for Indonesia's young generation to love and be proud of the history of the Indonesian nation's struggle. This writing uses the historical method, which consists of four stages, namely heuristics (the source collection stage), internal criticism (determining the source of the source) and internal criticism (determining source credibility), interpretation (analysis) data, and historiography (writing). The results of the search for the history of Bung Karno include: Bung Karno arrived in Bengkulu on May 9, 1938.
\end{abstract}

Keywords: Even, History, Bung Karno, Bengkulu.

Abstrak: Jejak Sejarah Bung Karno di Bengkulu. Penulisan ini bertujuan untuk melengkapi data sejarah tentang perjalanan perjuangan Bung Karno semasa pengasingannya di Bengkulu. Penulisan jejak sejarah Bung Karno di Bengkulu (1938 - 1942) selain bermanfaat bagi pengembangan penulisan sejarah bagi bangsa Indonesia, juga diharapkan bermanfaat sebagai bahan pendidikan sejarah bagi generasi muda Indonesia agar lebih mencintai serta bangga terhadap sejarah perjuangan bangsa Indonesia. Penulisan ini menggunakan metode sejarah, yang terdiri atas empat tahapan, yaitu heuristik (tahap pengumpulan sumber), kritik entern (menentukan autensitas sumber) dan kritik intern (menentukan kredibilitas sumber), interpretasi (analisis) data, dan historiografi (penulisan). Hasil penelusuran jejak sejarah Bung Karno antara lain: Bung Karno tiba di Bengkulu tanggal 9 Mei 1938.

Kata Kunci: Jejak, Sejarah, Bung Karno, Bengkulu.

\section{Pendahuluan}

Ada pertanyaan yang menarik untuk diajukan, yaitu kapan Bung Karno tiba di Bengkulu. Sebelum diketemukannya sumber sejarah dari kantor Arsip Nasional Republik Indonesia (ANRI), tanggal dan bulan tibanya Bung Karno di Bengkulu masih belum jelas. Ada salah satu sumber yang menyebutkan bahwa Bung Karno tiba di Bengkulu pada tanggal 14 Februari 1938, seperti yang diberitakan di media sosial sebagai berikut: "Bung Karno menjejakkan kaki di Bengkulu pada 14 Februari 1938.1 Sumber ini jelas tidak bisa dipakai sebagai referensi karena tidak akurat, bahkan tergolong sumber yang "impossible" (tidak mungkin). Tanggal 14 Februari 1938 adalah tanggal dibuatnya surat keputusan
Gubernur Jenderal Hindia Belanda untuk memindahkan tempat pengasingan Bung Karno dari Ende ke Bengkulu. Jadi tidak mungkin pada tanggal yang sama dan bulan yang sama Bung Karno dari Ende langsung tiba di Bengkul. Ada lagi Sumber lain menyebutkan bahwa : Soekarno tiba di Ende pada Februari 1934 dengan kapal Jan van Riebeeck dan meninggalkan kota ini pada Februari 1938 dengan kapal De Klerk milik KPM menuju Surabaya. ${ }^{2}$ Sumber inipun juga tidak logis, karena antara tanggal surat keputusan dengan tanggal keberangkatannya sama, yaitu samasama tanggal 14 Februari 1938. Demikian pula dengan sumber lain lagi, seperti tersebut di bawah ini: 
"Pada tanggal 14 Februari 1938, Bung Karno harus menyalani sisa masa pembuangan terakhir ke Bengkulen (Bengkulu) beserta keluarganya"3

Sumber ini juga tidak menyebutkan secara jelas kapan Bung Karno tiba di Bengkulu. Sementara itu, M.Ali Chanafiah mempunyai catatan tersendiri mengenai kapan Bung Karno tiba di Bengkulu. Berikut catatan M.Ali Chanafiah :

Begitulah pada permualaan Maret 1938 kami menerima berita dari Batavia, bahwa Bung Karno telah tiba di kota itu. Keluarganya terus ke Bandung. Dia sendiri langsung dilarikan ke Merak melewati Lampung dan dengan kereta api menuju Lubuk Linggau. Kemudian selanjutnya dengan bis terus ke Bengkulu. ${ }^{4}$

Catatan M.Ali Chanafiah di atas cukup masuk akal jika dikaitkan dengan turunnya Surat Keputusan Gubernur Hindia Belanda no. $2 z$ tertanggal 14 Februari 1938. Dengan catatan Bung Karno segera diberangkat dari Ende menuju Bengkulu pada bulan itu juga. Namun ada dua sumber lain yang justru menyebutkan bahwa Bung Karno meninggalkan Ende pada tanggal 18 Oktober 1938. Berikut petikan bunyi sumbernya:

Tanggal 18 Oktober 1938 merupakan hari yang sangat sedih bagi para sahabat Bung Karno. Bung Karno harus meninggalkan Ende. Waktu itu, malam sekitar pukul 20.00, Bung Karno dan keluarga diantar menuju dermaga Ende (Tim Nusa Indah, 2001: 87).

Setelah menyalani masa pembuangan di Pulau Flores selama empat tahun, sembilan bulan dan empat hari, pada tanggal 18 Oktober 1938 Bung Karno meninggalkan Ende dengan naik kapal yang akan membawanya ke Bengkulu. ${ }^{5}$

Kedua sumber di atas, meragukan karena jarak waktunya terlampau jauh dengan tanggal dan bulan surat keputusannya, yaitu dari bulan Februari ke bulan Oktober. Jika dihitung maka jarak waktu berangkat dengan tibanya memakan waktu delapan bulan lamanya. Padahal, perjalanannya yang sudah pernah dilaluinya sekitar delapan hari. Oleh karena sumber-sumber tersebut meragukan dan juga tidak didukung oleh arsip maupun dokumen sejarah, maka belum bisa dijadikan sebagai fakta sejarah yang akurat.

Ketiga sumber tersebut ternyata meleset setelah diketemukan dokumen di kantor Arsip Nasional Republik Indonesia (ANRI) khusus yang berkaitan dengan arsip Bung Karno. Berikut petikan bunyi dokumen arsipnya:

"blijkens het hiernevens inafschrift gaande geheim telegram van den Resident van Benkoelen van $9 \mathrm{Mei}$ jl. No.95 is Ir. Soekarno op $9 \mathrm{Mei}$ in Benkoelen aangekomen" 3

Berdasarkan petikan dokumen arsip tersebut di atas, dapat diketahui bahwa, berdasarkan isi telegram rahasia dari Residen Bengkulu yang dikirim kepada Gubernur Jenderal Hindia Belanda di Batavia, Bung Karno tiba di Bengkulu pada tanggal 9 Mei 1938. Dengan demikian terjawablah sudah persoalan mengenai kapan datangnya Bung Karno di Bengkulu yang berstatus sebagai orang buangan politik kolonial Belanda.

\section{Pembahasan}

\section{Dari Hotel Centrum ke Rumah Anggut Atas}

Sama seperti waktu pengasingan di Ende, Pemerintah Hindia Belanda memang tidak menyiapkan atau menyewakan rumah untuk tempat tinggal buangan politik. Sebagai buangan politik, Bung Karno harus mencari sendiri rumah sewaan untuk tempat tinggalnya. Sesuai dengan peraturan yang dikeluarkan oleh Pemerintah Hindia Belanda, Gubernur Jenderal Hindia Belanda hanya memberikan jaminan berupa tunjangan bulanan untuk memenuhi kebutuhan hidup setiap bulan. Tunjangan perbulannya sama ketika Bung Karno 
diasingkan di Ende, yaitu sebesar f.150 (seratus limapuh gulden). Oleh karena itu, begitu Bung Karno tiba di Bengkulu sasaran utamanya adalah mencari tempat penginapan dulu. Kebetulan ada sebuah tempat penginapan namanya Hotel Centrum yang letaknya tidak bergitu jauh dari tempat pemberhentian bisnya. Harihari pertama dipenginapannya, Bung Karno sering di temani oleh M. Ali Chanafiah dan Gunadi yang sudah dikenalnya sejak pertama kali tiba di Bengkulu.

M. Ali Chanafiah juga sering menemani Bung Karno untuk ngobrol di tempat penginapannya. Obrolannya seputar tentang keadaan kota Bengkulu dan kondisi masyarakatnya. Bahkan Bung Karno sering mengajaknya makan di Hotel Centrum. Bung Karno merasa kesulitan untuk bisa bergaul dengan masyarakat sekitarnya, termasuk juga para tokoh dan kaum pergerakan. Sebagian dari mereka masih diliputi perasaan takut bergaul dengan orang buangan politik. Mereka takut dibayangbayangi oleh polisi rahasia yang senantiasa mengawasi gerak gerak Bung Karno di Bengkulu. Apalagi gerak gerik aktvitas Bung Karno selalu mendapat pengawasan ketat dari Politiek Inlichtingen Dienst (polisi rahasia), yang disingkat PID. Tugasnya mereka mengawasi, mematamatai kaum pergerakan nasional seperti Bung Karno. Segala informasi dari PID tentang gerak gerik Bung Karno nantinya dilaporkan kepada Residen Bengkulu. Selanjutnya Residen Bengkulu akan membuat laporan politik kepada Gubernur Jenderal Hindia Belanda di Batavia. Oleh karena itulah tokoh-tokoh masyarakat serta kaum pergerakan yang mendekat dengan Bung Karno masih sangat terbatas. Bung Karno tidak ingin berlama-lama menginap di Hotel Centrum. Bung Karno ingin segera mendapatkan rumah sewaan untuk tempat tinggalnya nanti bersama keluarga, yaitu Inggit (istrinya), Ratna
Djuami dan Sukarti (anak angkatnya), serta Riwu Ga (pembantu setianya) yang saat ini masih di Bandung. Oleh karena itulah Bung Karno minta ditemani oleh M.Ali Chanafiah untuk mencari rumah yang bisa disewa untuk tempat tinggalnya. Bung Karno ditemani M. Ali Chanafiah mencari rumah sewaan di kampung Tengah Padang, yaitu kampungnya keluarga M. Ali Chanafiah yang jaraknya cukup dekat dengan Hotel Centrum.

Kampung Tengah Padang ini terkenal dengan kampungnya para Raden-Raden. Menurut catatan sejarah, pada waktu pecah perang antara Cakraningrat IV dengan Kompeni Belanda, dikirimlah Raden Temenggung Wirodiningrat (anak yang keempat) bersama dengan Raden Sang Nata (anak Raden Ranadiningrat) ke Bengkulu untuk minta bantuan Kompeni Inggris. Akan tetapi gagal, bahkan mereka akhirya menetap di Bengkulu. Sementara Cakraningrat IV sendiri ditawan oleh Kompeni Belanda dan selanjutnya dibuang ke Cape (Tanjung Harapan). Kehadiran kelompok raden keturunan Madura di Bengkulu ini, ternyata mendapat respon serta sambutan terhormat dari kalangan elite pribumi setempat. Perkembangan selanjutnya, kelompok raden keturunan Madura ini berhasil menyalin hubungan kekerabatan melalui perkawinan dengan keluarga elite pribumi setempat. ${ }^{4}$ Bung Karno bersama M.Ali Chanafiah mampir ke rumah orang tua M.Ali Chanafiah di kampung Tengah Padang. Bung Karno rupanya tertarik untuk menyewa rumah panggung kepunyaan orang tua M.Ali Chanafiah. Bung Karno pun menyatakan keinginannya untuk menyewa rumah tersebut. Keluarga M.Ali Chanafiah, terutama sang ayah, tidak keberatan rumah itu ditempati Bung Karno. Tetapi sang nenek yang sudah lanjut usia tidak ingin pergi dari rumah itu. Nenek M.Ali Chanafiah ingin menghabiskan sisa 
hidupnya dirumah itu. Artinya, keinginan Bung Karno untuk menyewa rumah itu batal. M.Ali Chanafiah merasa lega, Bung Karno tidak jadi menempati rumah orang tuanya di Tengah Padang, karena menurutnya rumah itu tidak layak untuk ditempati Bung Karno. Bung Karno masih menginap di Hotel Centrum untuk beberapa minggu, sambil menunggu kedatangan keluarganya, yaitu Inggit (istri), Ratna Djuami dan Sukarti (anak angkat), serta Riwu Ga (pembantu setianya).

Di tengah penantiannya, Bung Karno sering berjalan dengan bersepeda bersama M.Ali Chanafiah berkeliling menikmati suasana serta pemandangan seputar kota Bengkulu. Sekali-kali juga melewati tempat-tempat yang bersejarah peninggalan Inggris seperti Fort Marlborough (Benteng Marlborough) peninggalan Inggris yang dibangun pada tahun 1714 yang pada waktu itu dijadikan sebagai kantor pemerintah Hindia Belanda. Bung Karno berkeliling dengan bersepeda melewati tempat bersejarah yang lain seperti pemakaman (kuburan) orang-orang Inggris yang disebut "The Christians of Cemetery" (Kuburan OrangOrang Kristen/Eropa). Bung Karno juga sering melewati Kampung Cina tempat pertokoan orang-orang Tionghoa yang terletak tidak jauh dari Benteng Marlborough.

Sekitar sepuluh hari kemudian, keluarga Bung Karno (Inggit, Ratna Djuami, Sukarti, dan Riwu Ga) dikabarkan datang ke Bengkulu melalui jalur laut dengan menumpang kapal laut Sloet van den Beele. Bung Karno segera menyambutnya dengan gembira. Kaum perempuan yang sebagian terdiri dari perhimpunan Aisyiah, Muhammadiyah, serta perkumpulan Taman Siswa ikut menyambut kedatangannya keluarga Bung Karno. Bung Karno bersama kaum perempuan menyambutnya di dermaga kecil yang bernama Bom. Kapal yang mengangkut rombongan Inggit tidak bisa langsung menepi ke dermaga Bom, melainkan berhenti agak di tengah laut. Selanjutnya ada perahu yang datang menjemputnya dan mengangkutnya ke tepi dermaga Bom. Bung Karno segera mengajak keluarganya menuju Hotel Centrum untuk menginap beberapa hari sambil mencari rumah sewaan yang cocok untuk tempat tinggalnya.

Suatu hari Bung Karno menemukan sebuah rumah milik seorang Cina yang terletak di kampung Anggut Atas. Rumah tersebut dalam keadaan kosong tidak ada penghuninya. Nama pemilik rumah yang disewa oleh Bung Karno itu ternyata simpang siur. Ada beberapa nama yang berbeda dengan sumber yang berbeda pula. Menurut catatan M.Ali Chanafiah, rumah itu milik Liem Bwe Seng. ${ }^{6}$ Sumber lain menyebutkan rumah itu milik Tan Eng Cian, pengusaha suppliyer khusus bahan sembako untuk keperluan Pemerintah Hindia Belanda di Bengkulu. ${ }^{7}$ Ada sumber lain lagi yang menyebut rumah itu milik pedagang keturunan Tionghoa yang bernama Tyang Ceng Kwat. ${ }^{8}$ Bahkan masih ada tiga sumber lagi yang tidak kalah menariknya untuk dijadikan bahan komparasi referensi . Sumber pertama, menyebut bahwa rumah pengasingan di Bengkulu itu sebenarnya dihadiahkan oleh seorang muslim Tionghoa kepada Bung Karno. Sumber kedua, menyebutkan bahwa rumah tersebut semula adalah milik seorang pedagang Tionghoa yang bernama Lion Bwe Seng yang disewa oleh orang Belanda untuk menempatkan Bung Karno selama diasingkan di Bengkulu. Sumber ketiga, menyebutkan bahwa rumah yang ditempati oleh Bung Karno di Bengkulu itu adalah rumah bekas administratur onderneming van der Vossen yang punya pabrik kebun sirih di Pantai Panyang. Rumah itu kabarnya telah dibeli oleh seorang pengusaha keturunan Cina bernama Tan Eng Cian, penyuplai bahan pokok untuk kebutuhan pemerintahan Hindia Belanda. 
Rumah yang ditempati Bung Karno ini halaman yang cukup luas ini memiliki atap berbentuk limas. Bangunannya berbentuk empat persegi panyang, dengan dindingnya polos. Pintu dan jendela rumahnya berdaun ganda, berbentuk persegi panyang, dengan ventilasinya terdapat hiasan kisi-kisi. Rumah tersebut kondisinya masih kotor belum layak huni dan perlu perbaikan. Oleh karena itu, Bung Karno mulai memperbaiki rumah itu agar lebih cantik dan menarik. Bung Karno menata rumah, beranda depan, belakang, pekarangan, maupun halaman dipercantik dengan potpot bunga yang beraneka warna. Bung Karno tidak sendirian memperbaiki rumah sewaannya. Masyarakat setempat pun ikut membantunya secara sukarela dan gotong royong. Setelah semuanya beres barulah Bung Karno sekeluarga pindah ke rumah sewaannya di Anggut Atas. ${ }^{5}$

Bung Karno sekeluarga mulai menikmati hari hari pertama di rumah pengasingannya di Anggut Atas dengan hati yang nyaman dan senang, karena sudah tidak menginap lagi di hotel. Sejak itulah Bung Karno dan Inggit sudah mulai terbisa dengan leluasa menerima tamutamunya. Bung Karno maupun Inggit juga mulai berkenalan dengan masyarakat sekitarnya. Namun demikian gerak geriknya tetap diawasi oleh polisi rahasia. Bahkan polisi rahasia selalu mengawasi dan mencatat orang-orang yang bertamu ke rumah Bung Karno. Tamu yang sering datang ke rumah Bung Karno biasanya orang-orang yang sudah akrab sejak pertama kali Bung Karno datang ke Bengkulu. M.Ali Chanafi dan istrinya Salmiah Pane sering berkunjung ke rumah Bung Karno. Bahkan kadang membawa teman-teman sepergerakan diajak bertamu ke rumah Bung Karno. Suatu hari, M. Ali Chanafiah mengajak salah seorang teman pemimpin perkumpulan Taman Siswa dari Palembang, namanya Sri Hanung yang ingin berkunjung ke rumah Bung Karno. M.Ali Chanafiah juga mengajak temannya akrabnya Gunadi dan Suhud yang sudah dikenal Bung Karno sejak pertama kali datang ke Bengkulu. Suatu hari, Bung Karno mengundang guru-guru perguruan Taman Siswa ke rumahnya untuk mendemonstrasikan cara membuat dan menyajikan masakan khas Jepang, yaitu Sukiyaki. Bung Karno mempersilahkan para tamunya untuk duduk lesehan di rumah pengasingannya. Ditengahnya sudah disiapkan anglo (tempat memasak yang terbuat dari tanah liat) yang sudah ada kayu bakarnya, beberapa mangkok dan piring untuk menaruh bahan-bahannya. Sukiyaki merupakan salah satu jenis hidangan Jepang yang terdiri dari irisan daging, sayur-sayuran serta tahu yang dimasak dengan cara direbus perlahan. Sukiyaki dimasak dalam kuah yang sudah diberi sedikit bumbu, lalu semua bahan dimasak perlahan diatas anglo yang sudah ada apinya (sekarang kompor) dan langsung disantap hangat. Setelah semuanya beres, para tamunya Bung Karno kemudian dipersilahkan untuk menikmati hidangan bersama-sama.

\section{Jadi Mbah Dukun}

Semenjak menempati rumah di Anggut Atas, pergaulan Bung Karno dengan masyarakat dari berbagai kalangan semakin meluas. Di mata masyarakat, Bung Karno sudah semakin dikenal sebagai sosok yang penuh perhatian, serta berjiwa penolong. Bung Karno memang sering membantu warga masyarakat yang sedang tertimpa kesusahan, seperti terjerat hutang, terjerat kasus hukum, dan lain-lain. Bung Karno sendiri mengakui bahwa dirinya sudah seperti seorang dukun di kampung yang sering dimintai pertolongan untuk menyelesaikan berbagai macam persoalan yang dihadapi mereka.

Suatu hari ketika M. Ali Chanafiah dan Salmiah istrinya sedang berkunjung ke rumah Bung Karno, datang seorang perempuan setengah tua turun dari 
andong (delman) lalu menemui Bung Karno. Perempuan itu menceritakan tentang anaknya yang sedang berada dalam tahanan polisi karena telah dituduh menjual kerbau orang lain. Perempuan itu memohon kepada Bung Karno agar dapat membebaskan anaknya dari tuntutan hukum. Jikalau ceritanya seperti itu, maka anaknya jelas bersalah karena melanggar hukum, dan tidak mungkin terbebas dari hukuman. Bung Karno dengan bijaknya meminta agar perempuan itu bersabar, dan tetap semangat. Bung Karno berjanji untuk membantu mengatasi permasalahannya. Bung Karno kemudian memberikan uang satu ringgit kepada perempuan itu untuk membayar ongkos naik andong yang masih menunggunya. Perempuan itu menerimanya kemudian berpamitan dengan Bung Karno. Setelah perempuan itu pergi, Bung Karno kemudian berkata kepada Salmiah, bahwa uang yang telah diberikannya itu adalah semua uangnya. Artinya Bung Karno tidak memiliki uang lagi. Salmiah pun memahaminya, lalu membuka tasnya dan memberikan ganti uang satu ringgit kepada Bung Karno. ${ }^{9}$

Lain dengan cerita yang dikisahkan oleh Bung Karno sendiri. Ada seorang pegawai yang menuntut hak kepemilikan seekor kerbau dari seorang marhaen (petani/rakyat jelata). Dalam suasana ketakutan, marhaen itu datang ke rumah dan mengadukan nasibnya kepada Bung Karno yang dianggapnya sebagai seorang dukun. Baginya kerbau itu adalah harta satu-satunya. Oleh karena itu dia memohon kepada Bung Karno agar mendapatkan kembali kerbaunya yang sudah diambil alih oleh orang. Bung Karno lalu memberikan nasehat agar perkaranya dibawa ke pengadilan, dan Bung Karno berjanji akan membantunya dengan do'a. Tiga hari kemudian si marhaen itu mendapatkan kerbaunya kembali. ${ }^{10}$

Kabar tentang kepedulian Bung Karno terhadap masyarakat sekitarnya makin mendapat simpatik, bahkan sudah tidak lagi takut-takut mengunjungi rumah Bung Karno meski dibayang-bayangi oleh polisi rahasia. Suatu hari datang ke rumah Bung Karno, seorang pedagang dan sekaligus pemilik usaha pemerah susu yang sedang kesulitan keuangan meminta bantuan kepada Bung Karno agar dapat mengatasi kesulitannya. Orang tersebut yakin, bahwa Bung Karno dapat menyelesaikan masalahnya. Ternyata memang benar, Bung Karno mampu mengatasi masalahnya dengan cara menggadaikan bajunya.

Masyarakat setempat terhadap Bung Karno sebagai "orang pintar" (sebutan halus untuk menyebut seorang dukun yang mampu menyembuhkan berbagai macam penyakit)) semakin berkembang dan menyebar ke berbagai lapisan. Suatu hari ada seorang perempuan mendatangi rumah Bung Karno sambil menangis. Perempuan menceritakan keluhannya, bahwa ia sudah tujuh bulan tidak datang bulan (haid). Bung Karno mencoba menjelaskan bahwa dia bukan seorang dokter. Akan tetapi perempuan itu rupanya sudah terlanjur mempercayai Bung Karno sebagai orang pintar. Bung Karno tidak ingin mengecewakan, akhirnya Bung Karno mempraktekkannya sebagai orang pintar. Menurut pengakuan Bung Karno, perempuan itu pun sembuh dari penyakitnya. ${ }^{11}$

\section{Sayang Anak}

Bung Karno peduli dan sangat perhatian kepada anak-anak. Rasa kasih sayang kepada anak-anak itu sudah ditunjukkan sejak menikah dengan Inggit. Bahkan ketika masih di Bandung, Bung Karno dan Inggit telah mengadopsi seorang anak, yaitu Ratna Djuami, anak kakak perempuannya Inggit. Anak angkatnya itupun ikut dalam pengasingan ke Ende. Ketika di Ende, Bung Karno mengadopsi seorang anak, namanya Sukarti, anak perempuan pasangan keluarga Atmo Soedirjo dan Soeminem, 
dan juga seorang anak dari keluarga jauh Inggit namanya Djumir.12 Semasa pengasingannya di Bengkulu, Bung Karno memang tidak mengadopsi anak lagi. Namun demikian, Bung Karno masih tetap menujukkan perhatiannya dan rasa kasih sayangnya kepada anak-anak, meskipun itu anak orang lain. Bung Karno dalam penuturannya kepada Cindy Adams, mengakui bahwa, dia mengnggap anak orang lain itu seperti anaknya sendiri. Perhatian dan kasih sayang Bung Karno kepada anak-anak ini bisa jadi ada kaitannya dengan keinginan Bung Karno untuk mendapat anak keturunannya. Sementara itu, semenyak menikahi Inggit, Bung Karno memang tidak mendapatkan anak keturunan darinya. Bung Karno merasa senang sekali jika ada tamu yang datang ke rumahnya dengan serta merta membawanya anaknya yang masih kecil. Bung Karno sepertinya sudah lama mendambakan anak keturunan. Namun Bung Karno belum mendapatkan anak keturunannya semenyak menikah dengan Inggit yang usianya jauh lebih tua. Ketika di asingkan di Bengkulu, Bung Karno berusia 37 tahun, sedangkan Inggit sudah menjelang 50 tahun. Oleh karena Bung Karno mendapatkan anak keturunannya, maka sangat wajar pula bila Bung Karno sangat peduli, dan perhatian kepada anakanak kecil. Ada cerita tentang seorang kepala sekolah rakyat yang sering berkunjung ke rumah Bung Karno dengan membawa anak perempuannya yang masih kecil. Bung Karno sangat senang dengan anak itu, dan selalu memeluknya serta memangkunya. Bung Karno sangat respek dan salut dengan kepala sekolah itu yang tidak takut lagi dengan polisi intel yang selalu mengawasinya. Bahkan kepala sekolah itu telah menjadi sahabat akrab Bung Karno. ${ }^{13}$

Di antara anak-anak yang sering ditemui dan mendapat perhatian khusus dari Bung Karno, yaitu Ahmad, anak lakilaki Suryomiharjo yang masih berumur 10 tahun, yang rumahnya tidak jauh dari rumah Bung Karno di Anggut Atas. Bung Karno menuturkan bahwa dirinya juga sering bermain dengan Ahmad hingga berjam-jam lamanya. Bung Karno punya cerita tentang Ahmad. Suatu hari, Ahmad menangis karena diejek bahkan diludahi oleh anak seorang Belanda. Bung Karno pun segera menghampirinya, lalu mencoba mengusap air matanya yang basah hingga kering, serta menepuknepuk halus bahunya sambil menasehatinya agar bersabar (Cindy Adams, 2011: 168). ${ }^{7}$

\section{Bila Musim Durian Tiba}

Salah satu kesukaan Bung Karno adalah makan buah durian. Bung Karno tidak sekedar suka makan buah durian, tetapi juga pandai memilih buah durian yang masak dan yang tebal isinya, serta padai juga mengupasnya. M. Ali Chanafiah punya cerita tersendiri tentang kesukaan Bung Karno terhadap buah durian. Kata M.Ali Chanafiah, Bung Karno kalau pergi ke rumahnya sering sendirian, alias tidak mengajak istrinya Inggit. Sayang M.Ali Chanafiah tidak menjelaskan kenapa Bung Karno tidak pernah atau jarang mengajak istrinya ke rumahnya. Yangan-yangan ada kaitannya dengan keretakan rumah tangganya Bung Karno dengan Inggit. Tapi ini soal hobby Bung Karno yang suka makan buah durian. Jika cerita M.Ali Chanafiah ini terkait dengan kesukaan Bung Karno terhadap buah durian, maka hal ini tidak ada hubungannya dengan keretakan rumah tangga Bung Karno. Bisa jadi Inggit memang tidak suka makan buah durian hingga Bung Karno tidak sengaja mengajaknya ke rumah M.Ali Chanafiah. Bung Karno sering menyuruh oprang tua M. Ali Chanafiah untuk memborong buah durian. Katanya kalau pas lagi musim durian, uang seringgit itu bisa mendapatkan buah durian satu gerobak. Selain sering pesta durian di rumah M.Ali Chanafiah, Bung Karno juga sering makan durian di rumah Munzir Munir, mantan anak muridnya di Sekolah Hollandsch 
Inlandsche School (HIS) Muhammadiyah di Kebon Ros, Bengkulu. ${ }^{7}$ Mengapa Bung Karno lebih senang menyuruh orang tua M.Ali Chanafiah, maupu orang tua Munzir Munir untuk membelikan durian, daripada membeli sendiri. Padahal kalau lagi musim buah durian, banyak penyaja buah durian keliling, bahkan melewati jalan di depan rumah Bung Karno. Rumah Bung Karno memang terletak di pinggir jalan, tetapi jauh dari jalan, karena halamannya luas hampir mencapai 100 meter jaraknya dari jalan. Oleh karena itulah barangkali Bung Karno hampirhampir tidak mendengar teriakan para penyaja durian yang sedang melewati jalan di depan rumah Bung Karno. Sementara rumah M. Ali Chanafiah maupun rumah Munzir Munir letaknya di pinggir jalan dan jaraknya lebih dekat dengan jalan tempat mangkalnya para penyaja durian. Dengan demikian, M.Ali Chanafiah maupun Munzir Munjir lebih mudah mendapatkan buah durian karena lebih dekat dengan mangkalnya para penyaja buah durian. Barangkali itulah yang menjadi alasan Bung Karno lebih senang menyuruh orang tua M.Ali Chanafiah maupun orang tua Munzir Munir untuk membelikan atau memborongkan buah durian. Jika pesanan durian sudah siap di rumah M.Ali Chanafiah maupun di rumah Munzir Munir, Bung Karno segera dikabarinya. Begitu dapat kabar dari M.Ali Chanafiah maupun Munzir Munir, bahwa durian sudah siap, Bung Karno segera ke rumah mereka. Sebelum pesta durian dimulai, meja kursi disingkirkan, dan Bung Karno ikut pula meminggirkannya. ${ }^{8}$

\section{Tiada Hari Tanpa Bersepeda}

Salah satu alat transportasi roda dua pada masa Hindia Belanda yang digerakkan dengan menggunakan kedua kaki adalah sepeda. Orang Jawa menyebutnya pit yang diambil dari bahasa Belanda fiets. Masyarakat Melayu Sumatera pada umumnya menyebut ketangin - kretangin - keureta angin (Bengkulu - Aceh). Belakangan muncul istilah untuk memperjelas jenis sepeda pada zamannya, seperti sepeda ontel, sepeda unta, sepeda kebo, dan lain-lain. Ada juga istilahnya nuntuk menyebut jenisnya apakah itu sepeda laki-laki atau sepeda perempuan. Untuk jenis sepeda yang khusus dipakai oleh kaum perempuan (wanita), namanya dames (sepeda perempuan), dan untuk jenis sepeda yang khusus dipakai oleh laki-laki disebut heren (sepeda lanang/laki-laki). Sepeda jenis dames (sepeda perempuan) ini bisa dikendarai (dipakai) oleh laki-laki, sedang sepeda jenis heren (sepeda lakilaki/lanang) hanya bisa dipakai/dikendarai oleh kaum laki-laki saja, karena bentuknya memang didisain untuk kaum laki-laki.

Pada masa Kolonial Belanda, seseorang yang mengendarai sepeda menempati kedudukan sosial yang tinggi di masyarakat, karena pada waktu itu, orang-orang yang mengendarai sepeda adalah orang-orang Eropa, kaum bangsawan dan kaum priyai, atau kaum elite (kaum terpelajar). yang dipandang secara ekonomi sudah mapan. Lalu bagaimana dengan status Bung Karno sebagai seorang buangan politik. Apakah status sosial Bung Karno termasuk salah satu kaum elite hingga layak untuk memiliki sepeda. Jawabnya jelas termasuk kaum elite (kaum terpelajar),. orang yang terpandang dalam masyarakat, meskipun sebagai interniran politik. Secara ekonomi, Bung Karno mendapat tunyangan bulanan sebesar 150 gulden, merupakan ukuran yang cukup besar bagi kebanyak orang yang belum tentu mendapatkan penghasilan sebesar itu.

Semasa pengasingannya di Bengkulu, Bung Karno memang selalu mempunyai sepeda, dan selalu menggunakannya kemana saja. Ibaratnya tiada hari tanpa bersepeda. Akan tetapi tidak ada sumber sejarah yang menerangkan sejak kapan Bung Karno 
mempunyai sepeda, dimana tempat membelinya, jenisnya maupun merknya. Menurut catatan M.Ali Chanafiah, Bung Karno sering mengajak M.Ali Chanafiah bersepeda berkeliling menikmati suasana serta pemandangan seputar kota Bengkulu. Sekali-kali juga melewati tempat-tempat yang bersejarah peninggalan Inggris seperti Fort Marlborough (Benteng Marlborough) peninggalan Inggris yang dibangun pada tahun 1714 yang pada waktu itu dijadikan sebagai kantor pemerintah Hindia Belanda. Bung Karno berkeliling dengan bersepeda melewati tempat bersejarah yang lain seperti pemakaman (kuburan) orang-orang Inggris yang disebut " The Christians of Cemetery" (Kuburan OrangOrang Kristen/Eropa). Bung Karno juga sering melewati Kampung Cina tempat pertokoan orang-orang Tionghoa yang terletak tidak jauh dari Benteng Marlborough.

Pada suatu hari, Bung Karno ditemani oleh M. Ali Chanafiah ke kampung Tengah Padang mencari rumah sewaan untuk bersepeda ke kampung Tengah Padang. kota dengan bersepeda mencari rumah kontrakan yang layak untuk ditempatinya. Salah satu kampung yang dikunjungi Bung Karno adalah Kampung Tengah Padang. Tengah Padang pun dikunjungi Bung Karno bersama M.Ali Chanafiah mampir ke rumah orang tua M.Ali Chanafiah di kampung Tengah Padang. Jika cerita M. Ali Chanafiah ini benar, bisa jadi Bung Karno sudah memiliki sepeda sebelum menempati rumah sewaannya di Anggut Atas.

Bung Karno juga sering mengunjungi sekolah Taman Siswa tempat M. Ali Chanafiah dan istrinya Salmiah Pane mengajar di sana. Selanjutnya mengajak M. Ali Chanafiah berkeliling seputar kota Bengkulu. Biasanya sebelum berkeliling, Bung Karno mengajaknya mampir dahulu ke Toko Liem yang terletak di seberang lapangan sepak bola, Kampung Cina. Bung Karno pun segera turun dari sepedanya lalu masuk ke toko tersebut dan mengambil dua buah coklat kadang merk van houten kadang merk kwatta. M.Ali Chanafiah, terheran-heran dengan Bung Karno yang bisa mengambil coklat ke toko itu tanpa membayarnya. Dengan rasa penasaran, M. Ali Chanafiah pun menanyakannya langsung kepada Bung Karno. Ternyata itu dianggap merupakan ganti honorariumnya Bung Karno atas tulisannya yang dimuat di halaman iklan toko Liem yang menjual minuman dan makanan. ${ }^{14}$ Suatu hari Bung Karno bersama dengan M.Ali Chanafiah keliling bersepeda ke arah selatan hingga sampai pinggiran kota. Namun tidak sampai melewati batas yang sudah ditentukan, yaitu tidak boleh lebih dari $40 \mathrm{KM}$. Ketika melihat ada seorang petani yang sedang duduk istirahat di pinggir jalan disamping dua pikulan hasil taninya, Bung Karno berhenti dan turun dari sepedanya lalu menghampiri petani itu. Bung Karno kemudian bercakap-cakap dengan petani itu serta menanyakan tentang kehidupannya. Di lain hari, Bung Karno mengajaknya keliling dengan sepeda ke arah utara menuju kampung Pasar Bengkulu yang letaknya antara tepi laut dengan Sungai Bangkahulu. Di pinggiran tak jauh dari muaranya, Bung Karno berhenti sebentar melihat sebuah situs Fort York. ${ }^{9}$

Bung Karno segera melanjutkan perjalanannya menuju pantai sambil melihat para nelayan yang sedang menunggu hasil tangkapan ikan mereka. Bung Karnopun segera mendekati para nelayan itu dan bercakap-cakap dengan mereka serta menanyakan tentang kehidupan sehari-harinya. Lain lagi dengan cerita Boerhan Wahid soal Bung Karno yang selalu naik sepeda. Boerhan Wahid menuturkan, bahwa Bung Karno hampir setiap pagi keluar rumah dengan menaiki sepeda merk Fongers keliling kota Bengkulu. Bung Karno selalu 
berpenampilan rapi dengan setelan pakaian serba putih, berdasi, berkopiah hitam. Terkadang juga memakai kaca mata hitam sehingga kelihatan lebih menarik dan menawan. Bung Karno selalu menebar senyum kepada siapa saja yang ditemuinya di jalan. Bung Karno pernah memboncengkan seorang nenek yang mau berobat ke rumah sakit dengan sepedanya. Bung Karno tidak sekedar memboncengkan nenek itu ke rumah sakit, tetapi juga membantu mengurusinya sampai selesai urusannya. Bahkan Bung Karno pun sudah menyiapkan sebuah delman untuk mengantarkan nenek itu pulang ke rumahnya.

Untuk mencegah Bung Karno memboncengkan orang dengan sepedanya, Pemerintah Belanda melalui tangan Residen Bengkulu mengeluarkan peraturan khusus. Isinya adalah sebagai berikut: Pertama, setiap pemilik sepeda khususnya di dalam Kota Bengkulu tidak ada pengecualian, apakah dia seorang ambtenar (pegawai negeri) tidak dibenarkan sepedanya memakai bagaze untuk membonceng orang. Bila peraturan ini dilanggar, maka dikenankan denda sebesar f. 025 (dua puluh lima sen) atau hukum kurungan selama 3 (tiga) hari. Kedua, bagi penduduk yang tinggal di luar kota, dapat dibenarkan memakai bagaze guna untuk mengangkat barang jualan. Seperti buah-buahan, kayu bakar, beras. Pokoknya, bagazinya hanya digunakan untuk membawa kebutuhan hidup sehari-hari.

Namun demikian, gerak gerik Bung Karno masih tetap terus menerus diawasi oleh polisi intel. Peristiwa itupun tidak lepas dari laporan polisi intel ke atasannya. Setiap hari keluar dari rumahnya, selalu diikuti dua orang polisi reserse. Pekerjaan reserse ini adalah membuat laporan kepada atasannya; dimana Bung Karno bertandang (bertemu) dengan siapa dia berbicara hari itu. Apakah dia mengumpulkan orang banyak. Pendeknya, semua gerak gerik harus dilaporkan. Apalagi kalau polisinya lengah Bung Karno menghilang, tidak tahu dimana rimbanya, maka polisi reserse itu mendapat hukuman stering ares (masuk kurungan).

Suatu hari, Bung Karno mengendarai sepedanya berkunjung ke rumah Achmad (alias Achmad Kancil yang letaknya dekat pasar ikan Kampung Barukoto). Achmad Kancil itu pamannya Fatmah, seorang tokoh Muhammadiyah setempat yang sehari-hari pekerjaanya sebagai tukang jahit pakaian. Bung Karno segera mamasuki halaman rumah Achmad Kancil, menyandarkan sepedanya di bawah pohon jambu yang besar dan rimbun daunnya. Bung Karno tahu kalau gerak geriknya sedang diawasi oleh polisis rahasia. Oleh karena itu, setelah selesai urusannya dengan Achmad Kancil, Bung Karno berpesan agar sepedanya tetap di disitu, dan Bung Karno lalu pulang lewat pintu belakang tanpa diketahui oleh polisi rahasia yang terus mengawasi. Polisi rahasia itu mengira Bung Karno masih ada di dalam rumahnya Achmad Kancil. Padahal Bung Karno sudah pulang lewat dapur rumah terus menyusuri jalan Kampung Bugis. Selanjutnya Bung Karno pulang ke rumah Anggut naik delman. ${ }^{10}$

\section{Protes Soal Tabir}

Inggit punya cerita Inggit soal kebiasaan sehari-hari kaum perempuan kota Bengkulu pada umumnya. Kaum perempuan pada umumnya berpakaian model kebaya yang rapi dan menutupi badannya, sedangkan Inggit sendiri sudah terbiasa dengan gaya busana kebayanya yang sedikit terbuka sebagaimana yang biasa dipakainya ketika di Bandung. Kaum laki-laki tidak biasa mengajak atau membawa istri-istrinya. Mereka sepertinya berjalan masing-masing. Kalaupun ada acara hajatan atau pertemuan keagamaan seperti pengajian, mereka dipisahkan dengan sebuah tirai. Suatu hari Bung Karno bersama 
Inggit menghadiri rapat umum Muhammadiyah. Di tengah berlangsungnya rapat, Bung Karno menyela dengan mengajukan pertanyaan kepada panitianya mengapa dalam rapat itu harus dipasang tabir untuk memisahkan kaum wanita dan kaum lakilaki. Panitia dan anggota rapat tidak ada yang mampu menyawab pertanyaan Bung Karno. Mereka seolah-olah mendiamkan dan mengacuhkan protes Bung Karno. Bung Karno kecewa dan ujungnya meninggalkan rapat. Inggit pun kemudian mengikuti langkah Bung Karno. Sesampainya di rumah, Bung Karno menjelaskan kepada Inggit, bahwa pemasangan tabir itu merupakan lambang perbudakan bagi kaum perempuan. Bung Karno menegaskan, bahwa tabir itu tidak ada dalam aturan ajaran Islam.

Bung Karno akhirnya menulis
artikel tentang Tabir Lambang Perbudakan, yang dimuat di majalah Adil pada tanggal 21 Januari 1939. Koresponden "Antara" datang ke menemui Bung Karno untuk mewawancarinya. Bung Karno mengakui bahwa dirinya bersama Inggit meninggalkan rapat umum Muhammadiyah sebagai tanda protes dipasangnya tirai pembatas antara wanita dan laki-laki. Bung Karno dengan tegas mengatakan, bahwa tabir itu simbulnya perbudakan perempuan. Menurutnya, Islam tidak mewajibkan adanya tabir itu. Islam tidak memperbudakkan perempuan melainkan mengangkat derajat perempuan. Tabir adalah salah satu contoh dari hal yang tidak diperintahkan oleh Islam, tetapi diadakan oleh umat Islam. ${ }^{11}$

Bung Karno menghendaki, bahwa jika diadakannya suatu rapat yang menghadirkan kaum perempuan dan kaum laki-laki, tidak harus membatasi dengan menutup pakai tabir, tetapi cukup dengan memberikan jarak antara kaum laki-laki dan kaum perempuan. Kepada koresponden Antara, Bung Karno juga menjelaskan alasannya masuk dalam organisasi Muhammadiyah. Bung Karno masuk Muhammadiyah itu bukanlah berarti menyetujui semua hal yang ada di dalamnya. Bung Karno memandang bahwa di dalam dunia Muhammadiyah di Bengkulu ada terdapat elemen-elemen yang masih kolot sekali. Oleh karenanya Bung Karno masuk Muhammadiyah ingin mengabdi kepada Islam akan datang banyak perobahan. Di dalam konferensi pengajaran daerah Bengkulen, Bung Karno pernah mengatakan bahwa janganlah orang mengira, Bung Karno akan mengikuti semua aliran yang ada dalam dunia Muhammadiyah itu. Bung Karno ingin menjadi salah satu motor evolusi. Kepada koresponden Antara Bung Karno menegaskan :

"Sejarah dunia menunjukkan, bahwa selamanya ada perjoangan dan dialektik antara kuno dan muda, antara orthodoxie dan evolusi, antara kolot dan modern. Menurut Bung Karno, Islam sejati mau mengangkat derajat perempuan, akan tetapi orthodoxie menjadi rem besar bagi evolusinya perempuan itu. Orang yang memberantas orthodoxie itu selamanya mendapat rintangan. Lihatlah Kemal Ataturk, lihatlah Nabi kita sendiri. Saya mengetahui, bahwa banyak orang Islam, banyak sekali, akan mengatakan, bahwa visi saya tentang tabir perempuan tidak tepat, akan tetapi orthodoxie, wat dan nog? Bagi saya tabir itu adalah satu simbul perbudakan, yang tidak dikehendaki oleh Islam. Saya ingat bahwa dulu H. A. Salim pernah merobek tabir di salah satu rapat umum, - ya merobek, terangterangan! Di dalam pandangan saya, perbuatan beliau itu adalah satu perbuatan, yang lebih besar misalnya daripada menolong orang dari pahlawan air laut yang sedang mendidih atau masuk penyara karena delik sekalipun. Sebab perbuatan sedemikian itu minta keberanian moril yang besar. Apakah yang saya perbuat? Bukan menunjukkan keberanian yang besar, tetapi ... keluar dari itu rapat moril "sebagai protes", - als een laffe hond!"15

Penasaran dengan penjelasan Bung Karno, Koresponden Antara lalu 
mempertanyakan ulang mengapa Bung Karno Karno tidak memberitahukan terlebih dahulu kepada para pengurusnya tentang tabir itu. Bung Karno dengan tegas mengatakan bahwa dia sudah mengingatkan bahkan mereka juga sudah berjanji untuk tidak memasang tabir. Bung Karno justru merasa dikhianati, karena mereka sudah menyatakan sepakat untuk tidak memasang tabir lagi jika ada pertemuan. Namun kenyataannya ketika Bung Karno datang pada rapat Muhammadiyah, ternyata tabir masih dipasang. Oleh karena itulah Bung Karno mengambil sikap tegas keluar dari rapat bersama Inggit. Pada akhirnya Inggit menyaksikan tabir-tabir itu mulai diturunkan walaupun tidak semua tempat. Namun menurut Inggit itu sudah suatu perubahan. ${ }^{16}$

\section{Merancang Masjid Tua}

Di persimpangan jalan antara kampung Tengah Padang -Pengantungan - Peramukan - dan Pintu Batu, berdiri sebuah masjid tua. Sebagian ada yang menyebutnya Surau Gedang (Surau Besar). Disebut Surau Gedang, dimungkinkan karena bangunannya lebih besar dari bangunan surau-surau lainnya yang ada di kampung lain seperti Pengantungan, Peramukan, maupun di Pintu Batu. Sebagian orang juga menyebutnya sebagai Masjid Jamik. Sebutan Masjid Jamik bukanlah sebuah nama masjid, melainkan karena fungsinya sebagai tempat penampung atau pengumpul para jamaah yang lebih besar dari beberapa surau atau langgar dalam kegiatan beribadah, terutama kegiatan ibadah pada setiap hari jumat, yang sering disebut dengan istilah jum'atan. Masjid Jamik artinya masjid penyatu dari para jamaah dari surausurau maupun langgar-langgar yang kecil, terutama pada iabadah sholat jumat.

Konon, masjid Jamik ini didirikan oleh keturunan bangsawan dari Bugis, namanya Daeng Maroepa. Berikut cuplikan dari sumber tradisional yang menyebutkan tentang pendirian masjid Jamik :

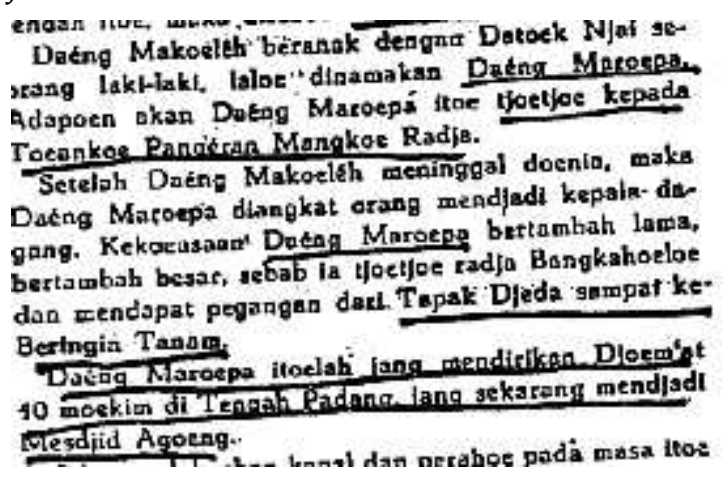

Daeng Makoeleh beranak dengan Datoek Nyai seorang laki-laki, laloe dinamakan Daeng Maroepa. Adapoen akan Daeng maroepa itoe coecoe kepada Toeankoe Pangeran Mangkoe Raja. Setelah Daeng Makoelah meninggal doenia, maka Daeng Maroepa diangkat orang menjadi kepala dagang. Kekoeasaan Daeng Maroepa bertambah lama bertambah besar, sebab ia coecoe raja Bangkahoeloe dan mendapat pegangan dari Tapak Jeda sampai ke Beringin Tanam.

Daeng Maroepa itroelah yang mendirikan Joemat 40- moekim di Tengah Padang, yang sekarang menjadi Mesjid Agoeng. ${ }^{17}$

Sayang sekali masjid tua ini terkesan dibiarkan dan tidak terawat dengan baik. Bung Karno melihat masjid yang kumuh dan sudah banyak yang rusak itu, timbul keinginan untuk memperbaiki agar masjid menjadi indah dan bersih. Bung Karno sudah menyiapkan rancangan untuk pembangunan masjid tua tersebut. Namun ternyata para orang tua di kota itu banyak yang menentangnya, bahkan memusuhi Bung Karno. Berikut pengakuan Bung Karno tentang masjid Jamik yang ada di kota Bengkulu pada waktu itu :

Mesjid kami keadaannya kotor, kolot dan tua. Aku kemudian membuat rencaana sebuah mesjid dengan tiang-tiang jang cantik, dengan ukiran timbul sederhana dan pagar tembok putih yang tidak ruwet dan kubujuk mereka untuk mendirikannja. Orang tua-tua dikota itu tidak suka kepada orang jang menginginkan perobahan. Keluarlah utjapan- 
utjapan jang tidak enak diantara kami dan pada permulaan aku membuat musuh. Hal ini terasa olehku sangat pedih. Terutama karena aku begitu haus akan kawan. ${ }^{18}$

Inggit juga menceritakan bahwa Bung Karno membuat rancangan sebuah masjid. Bung Karno jengkel dengan masjid-masjid yang ada, yang kotor, tidak diurus serta menunjukkan kekolotan dalam segala hal. Bung Karno membuat rancangan masjid itu secantik-cantiknya, dengan tiang-tiang yang langsing. Bung Karno dengan bangganya memperlihat gambar rancangan masjid itu kepada Inggit. Inggit tahu dan faham tentang Bung Karno suaminya yang ingin merancang masjid itu dengan mengutamakan keindahan dan kebersihan. Namun Inggit tidak mampu membayangkan seperti apa jadinya masjid hasil rancangan Bung Karno. Yang jelas Inggit memuji karya suaminya. Akan tetapi Inggit masih meragukannya. Bukan meragukan atas hasil rancangan suaminya, tetapi meragukan apakah para orang tua itu akan menerima hasil rancangan suaminya atau justru sebaliknya. Keraguan Inggit cukup beralasan, karena orang-orang tua baik yang dominan di masjid tua itu maupun para jamaahnya masih mempunyai pemikiran-pemikiran yang kolot dan sepertinya tidak menyukai adanya suatu perubahan. Sebaliknya Bung Karno justru lebih bersemangat dan bertekat untuk melakukan perubahan pada kondisi masjid tua yang kotor dan penghuninya yang kolot.

Ternyata benar apa yang menjadi keragu-raguan Inggit terhadap para orang tua yang ada disekitar masjid tua itu. Mereka bukannya menyambut baik rancangan Bung Karno yang akan memperbaiki kondisi masjid tua itu, melainkan mencemoohkan, bahkan memusuhi Bung Karno. Tentu saja Bung Karno merasa sangat sedih dan prihatin mendapatkan ejekan serta perlakuan yang tidak menyenangkan dari mereka. Sebagai seorang buangan politik, Bung Karno tentu saja ingin menambah kawan, mempererat tali persahabatan dengan berbagai macam lapisan masyarakat, serta ingin berbuat sesuatu yang baik bagi masyarakat sekitarnya. Namun ketika Bung Karno sudah menyiapkan rancangan bangunan untuk masjid tua itu justru mendapat respon yang negatif. Sementara itu, Bung Karno masih harus terus berhadapan dengan polisi kolonial yang selalu mengawasi dan mencatat semua orang yang berhubungan dengan Bung Karno. Di tengah kegelisahan serta kesedihan hati Bung Karno, sang istri tercinta Inggit mengambil sebagai penasehatnya. Inggit yang lebih tua usianya, mencoba memberikan nasehat kepada suaminya, Koesno (panggilan kesayangan untuk Bung Karno). "Mendekati orang haruslah dengan caracara yang bakal menyenangkan, bukan dengan cara-cara yang bakal menyusahkan sendiri. Mereka yang terbelakang itu harus dikasihani, harus dibimbing, dan bukan diejek atau dimarahi," demikian nasehat Inggit kepada Bung Karno. ${ }^{19}$

Bung Karno menyadari bahwa mendekati orang-orang tua yang kolot memerlukan kesabaran serta ketelatenan. Bung Karno mencoba mendekati orangorang yang berpengaruh terhadap golongan orang tua, serta membujuknya dengan kesabaran agar mereka mau memperbaiki masjid mereka yang sudah rusak. Bung Karno menujukkan niatnya yang tulus ikhlas dengan memperlihatkan rancangannya yang sudah dipersiapkan. Dihadapan mereka Bung Karno bersedia menyisihkan sebagian dari tunyangan bulannya yang didapatkan dari kantor Pemerintah Hindia Belanda untuk menjadi donatur tetap. Bahkan Bung Karno siap ikut terlibat kepanitiaan untuk penggalangan dana pembangunan masjid Jamik. Para orang tua di masjid Jamik itu Pada akhirnya bisa menerimanya. Bung Karno sendiri menurut catatan arsip, 
setiap bulannya menyumbangkan uang sebesar f.1(satu gulden) untuk pembangunan Masjid Jamik, dan f. 0,5 untuk masjid yang terletak di seberang rumahnya. ${ }^{12}$ Sebagai lulusan Technishe Hooge School (THS)yang bergelar Insinyur, Bung Karno ternyata tidak hanya membuat rancangan untuk masjid Jamik saja, tetapi juga membuat rancangan bangunan untuk sekolahan juga untuk perumahan. Menurut catatan M.Ali Chanafiah, Bung Karno membuat rancangan bangunan untuk gedung sekolah Taman Siswa yang terletak di Kampung Tengah Padang. Namun sayang bangunan gedung rancangan Bung Karno yang baru setengah jadi, Jepang keburu masuk Bengkulu, sehingga bangunan tersebut tidak terselesaikan. Namun tiga buah rancangan bangunan rumah berhasil dirampungkan. Dua buah bangunan rumah milik Komisaris Redaktur yang bekerja di kantor Residen dan satunya lagi bangunan rumah milik Asisten Demang. ${ }^{20}$

\section{Pengurus Muhammadiyah dan Taman Siswa}

Sebelum Bung Karno masuk dalam kepengurusan atau menjadi bagian dari organisasi sosial seperti Muhammadiyah, maupun Taman Siswa, Bung Karno sebetulnya sudah akrab dengan para pengurusnya. Bung Karno sudah saling kenal mengenal dengan tokoh-tokoh pergerakan baik dari Taman Siswa maupun Muhammadiyah seperti M.Ali Chanafiah, Semaun Bakri, Gunadi, dan Salmiah Pane, dan lain-lain. Namun secara formal Bung Karno belum menjadi pengurus dari kedua perguruan tersebut.

Suatu pagi hari, Bung Karno kedatangan tamu seorang pengurus Muhammadiyah setempat, namanya Hassan Din. Setelah saling memperkenalkan diri, Hassan Din menyampaikan kabar bahwa perkumpulan perguruan Muhammadijah di Bengkulu yang sedang menyelenggarakan sekolah rendah agama mengalami kekurangan guru. Hassan Din juga mendengar kabar, bahwa selama di Ende Bung Karno telah menyalin hubungan dengan Persatuan Islam (PI) di Bandung, serta sepaham dengan Ahmad Hassan, guru yang cerdas itu. Oleh karena itu, Hassan Din menawarkan kepada Bung Karno untuk membantu sebagai guru di sekolah tersebut. Mendengar tawaran dari Hassan Din. Tentu saja Bung Karno menerimanya dengan senang hati. Namun, Hassan Din menerimanya dengan suatu syarat, bahwa Bung Karno harus berjanji tidak mengajarkan atau bicara soal politik dalam mengajar di sekolah Muhammadiyah. Bung Karno pun bersedia menerima syarat yang dikemukakan oleh Hassan Din. Bung Karno juga memintanya agar diperbolehkan untuk memberikan pelajaran yang menyinggung tentang Nabi Besar Muhammad yang selalu mengajarkan kecintaan terhadap tanah air. ${ }^{21}$ Hassan Din sangat menyetuju usulan Bung Karno. Setelah selesai pembicaraan, Hassan Din segera berpamitan dengan Bung Karno yang juga disaksikan oleh Inggit dengan rasa senangnya.

Inggit dapat memahami arah pembicaraan Bung Karno tentang cinta tanah air. Menurut Inggit, Bung Karno tentu saja akan mengembangkan yang lebih luas sesuai dengan cita-cita suaminya. Semenyak Bung Karno giat mengajar di Muhammadiyah, Inggit juga merasa lebih senang dan bisa menikmati kehidupan di kota Bengkulu. Bung Karno sering mengajak keluarga termasuk juga Riwu pembantu setianya pergi jalan-jalan ke pantai. Pembantu rumah tangga Bung Karno juga sudah bertambah dua orang. ${ }^{13}$ Bung Karno tidak hanya mendidik anakanak di sekolah Muhammadiyah saja, tetapi juga mendidik anak-anak lain, terutama Ratna Djuami maupun Sukarti (Kartika) anak angkatnya sendiri. Dalam berbagai kesempatan Bung Karno selalu memberikan nasehat dan pelajaran kepada Ratna Djuami maupun Sukarti 
agar menjadi anak yang mandiri, percaya kepada diri sendiri, tidak cengeng dan tidak pengecut. Bung Karno menggembleng kedua anaknya agar memilii karakter, kepribadian, dan mempunyai corak sendiri. Bung Karno juga memberikan nasehat kepada anakanaknya, agar tidak seperti pohon cemara yang selalu mengikuti tiupan arah angit. Tertiup angin ke barat ikut ke barat, tertiup angin ke timur ikut ke timur. Bung Karno juga memberikan gemblengan secara khusus kepada Omi (panggilan kesayangan untuk Ratna Djuami) agar dapat menirukan suara Bung Karno yang kencang dan meledakledak. Untuk melatih agar suara Omi bisa seperti suara ayahnya, Bung Karno sering mengajaknya ke pantai. Di sana Bung Karno kadang hampir sampai seharian mengajari Omi melatih vokalnya di antara suara gemuruh debur ombak pantai. Tentu saja suara Omi yang cenderung lembut dan lirih nyaris tidak terdengar dalam jarak tertentu karena kalah dsengan suara deburan ombak pantai. Omi sendiri merasa tidak mampu menuruti kemauan ayahnya (Bung Karno) agar bisa meniru suaranya yang menggeledek. Akhirnya Omi pun curhat kepada sang ibu, Inggit. Kepada Omi, Inggit pun memberikan nasehat yang cuup bijak. Inggit tetap memberikan semangat kepada anaknya agar tetap berlatih, meskipun tidak mampu menghasilkan suara seperti ayahnya, tetapi lambat laun akan mampu memperlancar berpidato. ${ }^{22}$

Bung Karno juga memberikan donasi setiap bulannya kepada perguruan Muhammadiyah, pantai asuhan, dan perkumpulan Aisyah sebesar f. 1,25 (satu seperempat gulden). Berikut petikan salah satu pengeluaran Bung Karno setiap bulannya :

contributies Muhammadiyah, weeshuis, Aisyah, etc. f. 1,25 (Bijlage : Afschrift : Een beeld van de maandelijksche uitgaven voor de huishouding van Ir. Soekarno geinterneerde te Benkoelen, Binnenlandsch Bestuur, ANRI, 2076).

Dalam perkembangannya, Bung Karno tidak hanya membantu sebagai guru di sekolah Muhammadiyah saja, tetapi dikemudian hari memegang jabatan sebagai Ketua Majelis Pengajaran. Pengaruh Bung Karno di kalangan Muhammadiyah semakin besar. Oleh karenanya setiap ada agenda rapat yang membahas sesuatu hal, usulan Bung Karno selalu mendapat respon baik. Suatu hari ketika diadakan rapat pimpinan Muhammadiyah yang dihadiri oleh para pucuk pimpinan Muhammadiyah antara lain: Bung Karno, Zainul, Hassan Din, Yahya Pasar Baru, Ahmad Kancil, Navi, dan juga Bung Karno.

Agenda utama rapat yaitu untuk menentukan siapa calon pengganti konsul Muhammadiyah Cabang Bengkulu $\mathrm{H}$. Junus Djamaludin sedang dalam kondisi sakit parah. Dalam rapat tersebut, ada beberapa nama yang diusulkan sebagai calon ketua Konsul. Akan tetapi Bung Karno tidak menyetujui nama-nama tersebut, karena mereka lebih cenderung menonjolkan kedaerahan. Selanjutnya Hassan Din menyodorkan satu nama lagi, yaitu Oey Tjeng Hien, yang posisinya ada di daerah Bintuhan, wilayah Bengkulu Selatan. Mendengar nama Oey Tjeng Hien, Bung Karno menyetujuinya, dan memintanya agar segera diundang ke Bengkulu. Pimpinan Muhammadiyah segera mengirim telegram ke Bintuhan yang ditujukan kepada Oey Tjeng Hien. Isi telegram menyatakan agar Oey Tjeng Hien segera ke Bengkulu menemui Bung Karno. Oey Tjeng Hien pun akhirnya datang ke Bengkulu dan menemui Bung Karno di rumah Anggut Atas. Bung Karno meminta agar Oey Tjeng Hien bersedia menjadi Ketua Konsul Muhammadiyah untuk menggantikan Ketua lama yang sedang sakit-sakitan. Oey Tjeng Hien bersedia asalkan domisilinya tetap di Bintuhan, karena usahanya, rumahnya, 
hartanya, dan semuanya asetnya ada disana. Bung Karno berusaha tetap membujuknya agar Oey Tjeng Hien bersedia menetap di Bengkulu. Bung Karno berusaha meyakinkan agar semua harta kekayaan Oey Tjeng Hien yang di Bintuhan dijual semua, lalu membuka usaha di Bengkulu. Bung Karno memberikan jaminan dengan keahliannya sebagai seorang arsitek, akan membantu Oey Tjeng Hien mendirikan perusahaan meubel. Tidak hanya itu saja, Bung Karno juga berjanji tidak akan meminta sepersenpun hasil keuntungan dari perusahaan meubel tersebut. Mendengar keseriusan Bung Karno, Oey Tjeng Hien bersedia menjadi Ketua Konsul Muhammadiyah dan bersedia pula untuk pindah ke Bengkulu. Setelah sepakat, Oey Tjeng Hien kemudian pulang ke Bintuhan untuk menyelesaikan urusannya dan berjanji segera kembali ke Bengkulu. Hubungan Bung Karno dengan Oey Tjeng Hien semakin akrab setelah pindah dan menetap di kota Bengkulu. Sesuai dengan hasil kesepakatan berdua, Bung Karno kemudian menjalin kerjasama dengan Oey Tjeng Hien untuk mendirikan perusahaan Meubel yang diberi nama Meubel Sukamerindu. Tentu saja modalnya semua dari Oey Tjeng Hien. ${ }^{23}$

Bung Karno membantu merancang berbagai model dan bentuk produk meubelnya. Salah satu karya meubel Bung Karno yaitu meja hias. Ketika ada pasar malam, perusahaan meubel Sukamerindu juga ikut memamerkan berbagai jenis meubel hasil rancangan Bung Karno. Kebetulan M.Ali Chanafiah bersama istrinya Salmiah juga datang ke pasar malam dan bertemu dengan Bung Karno. Bung Karno kemudian meminta Salmiah agar membeli meja hias hasil buatannya. Rupanya Bung Karno sengaja memperiapkan dua buah meja hias pada acara pasar malam. Satu meja hias dibeli Salmiah, dan satunya lagi, katanya untuk Fatmah. ${ }^{14}$

\section{Menggagas Konferensi Besar Daerah}

Bung Karno yang sudah dipercaya sebagai ketua Majelias Pengajaran Muhammadiyah Bengkulu, berkeinginan merancang sebuah kegiatan untuk mengumpulkan para pengurus Muhammadiyah dari berbagai daerah Sumatera. Bung Karno ingin berdialog dengan para tokoh Muhammadiyah untuk menanamkan rasa cinta kepada agama, tanah air dan bangsanya. Untuk merancang hal tersebut, Bung Karno berdiskusi dengan Oey Tjeng Hien selaku Konsul Muhammadiyah Bengkulu. Bung Karno berpendapat bahwa yang diundang nanti dibatasi para pemimpinnya atau ketuanya saja, seperti ketua Konsul, ketua Tarjih, ketua Pengajaran, ketua Aisyiah Ketua Pemuda Muhammadiyah, masingmasing setiap daerah satu orang. Bung Karno kemudian menanyakan kepada Oey Tjeng Hien, mengenai siapa saja yang perlu diundang untuk membahas kegiatan tersebut. Oey Tjeng Hien mengusulkan Semaun Bakrie selaku wakil Majelis Pemuda Muhammadiyah Bengkulu, dan Haji Yunus Abdur Rahman, selaku Ketua Majelis Tarjih. Bung Karno menyetujui usul Oey Tjeng Hien. Bung Karno kemudian menemui Semaun Bakrie, A.R. Abdullah, Rasyid Thalib, serta Haji Yunus Abdur Rahman. Rasyid Thalib mengusulkan nama yang dipakai untuju kegiatan tersebut, yaitu Konferensi Daeratul Kubra, yang artinya Konferensi Besar Daerah. Bung Karno menyetujui nama ysng trelsh diusulkan oleh Rasyid Thalib tersebut.

Bung Karno sebagai interniran politik pemerintah Belanda menyadari tidak mungkin mengambil posisi sebagai pucuk pimpinannya, tetapi semua kepanitiannya ditentukan oleh Bung Karno. Bung Karno segera membentuk kepanitiaan secara lengkap. Penanggungjawab keseluruhan dipercayakan kepada Oey Tjeng Hien selaku Konsul. Bung Karno meminta Oey Tjeng Hien segera mengirim surat persetujuan sekaligus undangan kepada 
Hoofd Bestuur (Pengurus Besar) Muhammadiyah di Yogyakarta yang diketuai oleh K.H. Mas Mansur. Oey Tjeng Hien juga mengirim surat undangan kepada konsul-konsul Muhammadiyah seluruh derah Sumatera. Undangan untuk para pucuk pimpinan Muhammadiyah wilayah Sumatera antara lain ditujukan kepada: Teuku Hassan, dan staf konsulnya (Aceh), Hamka, staf konsulnya (Medan), A.R. Sutan Mansur dan staf konsulnya (Sumatera Barat), Abdul Muin dan staf konsulnya (Tapqanuli), R.Z. Fananie dan staf konsulnya (Palembang), Konsul Riau, Konsul Jambi, serta Konsul Lampung. Ketua panitia penyelenggara Konferensi Daeratul Kubra dipercayakan kepada Hamdan Mahyudin. Untuk menjamim kenyamanan para tamu undangan, Bung Karno sendiri memegang kendali bagian perlengkapan dan logistik. Seksi konsumsi diserahkan kepada Yahya dan istrinya (Pasar Bengkulu).

Suatu ketika menjelang persiapan pelaksanaan Konferensi, Bung Karno dan Oey Tjeng Hien diundang oleh Hamdan Mahyudin selaku ketua panitia. Menurut cerita Oey Tjeng Hien, ketika Hamdan Mahyudin mempersilahkan Bung Karno untuk meneikmati hidangan yang telah disediakannya, Bung Karno menanyakan dengan tegas terlebih dahulu apakah semua hidangan ini biayanya berasalah dari panitia, atau dari uang pribadi. Hamdan Mahyudin dengan gugup menjawab bahwa hidangan itu semua dikeluarkan dari uang pribadinya. Mendengar jawaban tersebut, barulah Bung Karno bersedia menikmati hidangan yang disuguhkan oleh Hamdan Mahyudin. Artinya, Bung Karno betulbetul memperhatian soal-soal sepele seperti itu. Bung Karno menegaskan, bahwa jika hidangan yang disuguhkan kepadanya itu uangnya dari panitia, maka haram baginya. Tetapi jika itu dari uang pribadi Hamdan Mahyudin, Bung Karno menghalalkan untuk memakannya. ${ }^{24}$ Menjelang pelaksanaan Konferensi
Muhammadiyah Daeratul Kubro digelar, Bung Karno dan Oey Tjeng Hien dipanggil oleh Residen Bengkulu yang baru yaitu Cornelis Eduard Maier (bukan Hooykaas seperti yang ditulis oleh Oey Tjeng Hien). Residen Maier mempertanyakan tentang penyelenggaraan Konferensi Daeratul Kubro. Oey Tjeng Hien selaku penanggungjawab kegiatan menjelaskan bahwa kegiatan sosial dan pendidikan dilakukan untuk kemajuan sekolah dan dakwah pendidikan Muhammadiyah di dearah Sumatera. Mendengar penjelasan dari Oey Tjeng Hien, Residen Maier tidak memberikan reaksi yang negatif. Namun pada malam harinya Bung Karno dijemput oleh petugas polisi dan ditahan di Benteng Marlborough. Peristiwa penahanan Bung Karno mendapat reaksi keras dari tokoh pimpinan Muhammadiyah, terutama Oey Tjeng Hien, selaku Konsul Muhammadiyah Bengkulu. Oleh karena hingga pagi Bung Karno masih di tahan di Benteng, Oey Tjeng Hien mendatanginya dan menanyakan alasan menahan Bung Karno. Para petugas di Benteng ternyata tidak ada yang bisa memberikan penjelasan. Oey Tjeng Hien dengan suara lantang bernada mengancam mereka, bahwa jika Bung Karno ditahan karena urusan Muhammadiyah mengadakan kegiatan Konferensi Daeratul Kubro, maka dia akan mengadukannya kepada Hoofd Bestuur (Pengurus Besar) Muhammadiyah di Yogyakarta. Rupanya Residen Bengkulu Maier yang telah mendapat laporan dari petugas keamanan di Benteng dan juga laporan dari polisi rahasia mempertimbangkan resiko yang akan terjadi jika menahan Bung Karno tanpa alasan yang jelas. Di samping itu, Bung Karno yang sudah berstatus sebagai bannelingen (orang buangan) tidak memungkinkan lagi menjalani status double tahanan. Oleh karenanya, Menjelang petang Bung Karno dibebaskan dari tahanan di Benteng Marlborough. 
Menjelang hari pelaksanaan Konferensi Daeratul Kubro, Bengkulu mulai rame karena banyak tamu undangan mulai berdatangan. Pengurus Besar Muhammadiyah K.H. Mas Masur dari Yogyakarta sudah datang di Bengkulu, bersama dengan tamu-tamu undangan lainnya. Bung Karno dan Oey Tjeng Hien pun segera menyambut para tamunya dengan mengunjungi tempat para tamu diingapkannya. Para tamu undangan merasa senang sekali dapat bertemu langsung dengan sosok Bung Karno, seorang tokoh pergerakan nasional yang sudah sangat terkenal luas di kalangan masyarakat Indonesia pada umumnya, dan sangat dibanggakan terutama oleh para tokoh Muhammadiyah. Acara resepsi pembukaan Konferensi Daeratul Kubro, yaitu di gedung Royal Cinema. Gedung yang cukup besar itu sampai penuh tamunya hingga melimpah keluar gedung. Bung Karno juga hadir dalam acara pembukaan tersebut. Acara Konferensi daeratul Kubro mulai dilaksanakan pada besuknya. Acara dibuka oleh tuan rumah, yaitu Oey Tjeng Hien selaku Ketua Konsul. Dalam sambutannya, Oey Tjeng Hien menyampaikan terima kasih kepada para tamu undangan utusan dari berbagai daerah yang sudah berkenan datang ke Bengkulu untuk menghadiri Konferensi Muhammadiyah Daeratul Kubro. Hamdan Mahyudin selaku ketua panitia pelaksana juga memberikan laporan tentang penyelanggaraan Konferensi Daeratul Kubro. Selanjutnya sebelum agenda sidang dimulai, diadakan pemilihan terlebih dahulu untuk menentukan siapa yang menjadi ketua sidangnya. Para peserta konferensi, sepakat untuk mengusulkan nama Udin Syamsudin wakil dari Sumatera Barat menjadi Ketua Sidang. Udin Syamsudin kemudian meminta agar Bung Karno bersedia mendampinginya sebagai sekretaris Sidang. Akhirnya dengan suara bulat sepakat terpilihlah Udin Mahyudin sebagai Ketua Sidang dan Bung Karno sebagai Sekretaris Sidang. Acara konferensi telah berlangsung hingga beberapa hari. Hasil akhirnya, telah dirumuskan beberapa keputusan, antara lain: perlunya peningkatan tenaga pengajar, peningkatan kualitas pendidikan, menyeimbangkan mata pelajaran agama dengan mata pelajaran umum, menyempurnakan kurikulum, metode pengajaran, serta menyempurnakan tata administerasi sekolah dan administrasi perserikatan. ${ }^{15}$

Acara penutupan Konferensi Daeratul Kubro berupa resepsi sekaligus malam perpisahan bagi para peserta dilaksanakan di rumah Oey Tjeng Hien. Sebelum diadakan jamuan makan malam, terlebih dahulu diberikan kesempatan kepada para konsul dari beberapa daerah untuk menyampaikan kata sambutannya. Acara sambutan dimulai dari tuan rumah, Oey Tjeng Hien, lalu para konsul, kemudian disusul sambutan dari Pengurus Besar Muhammadiyah K.H. Mas Mansur. Bung Karno yang pada waktu acara pembukaan tidak menyampaikan pidatonya, pada malam penutupannya memberikan pidatonya. Pada umumnya sambutan-sambutan tersebut lebih bersifat menceritakan pengalamannya masing-masing, suka dukanya, bahkan banyak yang lucu-lucu sehingga suasananya menjadi riang gembira. Keesokan harinya, para peserta sudah berkemas-kemas untuk meninggalkan Bengkulu pulang ke daerahnya masing-masing. ${ }^{25}$

\section{Kesimpulan}

Pemerintah Hindia Belanda memang tidak menyiapkan atau menyewakan rumah untuk tempat tinggal buangan politik. Sebagai buangan politik, Bung Karno harus mencari sendiri rumah sewaan untuk tempat tinggalnya. Sesuai dengan peraturan yang dikeluarkan oleh Pemerintah Hindia Belanda, Gubernur 
Jenderal Hindia Belanda hanya memberikan jaminan berupa tunjangan bulanan untuk memenuhi kebutuhan hidup setiap bulan. Tunjangan perbulannya sama ketika Bung Karno diasingkan di Ende, yaitu sebesar f.150 (seratus limapuh gulden).

Ketika di bengkulu bung karno banyak terlibat dalam aktifitas seperti merancang Masjid Jamik aktif di kepengurusan Muhammadiyah dan Taman Siswa dan Menggagas Konferensi Besar Daerah.

\section{Referensi}

\begin{tabular}{l}
\hline${ }^{1}$ travel.kompas.com , travel, 8 Okt \\
2013). \\
${ }^{2}$ rizkypein.blogspot.com/2016/12/ bung- \\
karno-di-ende-part-1). \\
${ }^{3}$ https://ndaru999.blogspot.com sejarah \\
dan biografi pahlawan). \\
${ }^{4}$ M.Ali Chanafiah, 2003:22-23). \\
${ }^{5}$ endefloresntt.blogspot.com/2014/ \\
singkat-pengasingan-bung-karno.html). \\
${ }^{6}$ M.Ali Chanafiah, 2003:31. \\
${ }^{7}$ asosiasimuseum \\
org/galeri/2-single./58-museum-rumah-bung- \\
karno.html). \\
${ }^{8}$ travel.kompas.com > Travel. \\
${ }^{9}$ M.Ali Chanafiah, 2003:34. \\
${ }^{10}$ Cindy Adams, 2011:170. \\
${ }^{11}$ Cindy Adams, 2011:170. \\
${ }^{12}$ Cindy Adams, 2011: 168. \\
${ }^{13}$ Cindy Adams, 2011: 167. \\
${ }^{14}$ M.Ali Chanafiah, 3003: 38. \\
${ }^{15}$ A. Dahlan Ranuwirja, 2001:56-57. \\
${ }^{16}$ Ramadhan KH, 2011:318. \\
${ }^{17}$ H.Delais, J. Hassan, 1933: 62. \\
${ }^{18}$ Cindy Adams, 2011: 167. \\
${ }^{19}$ Ramadhan KH, 2011:319. \\
${ }^{20}$ M.Ali Chanafiah, 2003:54. \\
${ }^{21}$ Cindy Adams, 2007:168. \\
${ }^{22}$ Ramadhan KH, 2007: 323. \\
${ }^{23}$ H.Abdul Karim, 1982: 57-60. \\
${ }^{24}$ Oey Tjeng Hien, 1982:67-68. \\
${ }^{25}$ Oey Tjeng Hien, 1982: 71. \\
Bung Karno diarahkan ke penginapan \\
terdekat, yaitu Hotel Centrum yang
\end{tabular}

letaknya tidak jauh dari tempat pemberhentian bus.

2 Jaraknya sekitar 600 meter dari rumah M. Ali Chanafiah (M. Ali Chanafiah, 2003: 20-27).

3 ANRI: Binnenlandsch-Bestuur, 2076.

4 Pangeran Sungai Lemau telah memberinya tempat tinggal, yaitu di kampung Tengah Padang (Agus Setiyanto, 2010: 63-63).

5 Malam harinya Bung Karno mengajak keluarga untuk menikmati suasana malam di kota Bengkulu (Ramadan $\mathrm{KH}$, 2011:315)

6 Cerita M.Ali Chanafiah sebagai salah satu saksi sejarah yang diundang ke rumah Bung Karno (M.Ali Chanafiah,2003:33).

7 Begitu perhatiannya Bung Karno kepada anak kecil yang bernama Ahmad ini, sampai-sampai nama anak kecil itu dimasukkan oleh Bung Karno sebagai salah satu pemeran dalam penulisan lakon sandiwara tonil Monte Carlo, yang berjudul Chungking Jakarta (Agus Setiyanto, 2006: 158).

8 Menurut catatan M.Ali Chanafiah, Bung Karno dengan posisi jongkok mengupasnya, dan terus melahapnya bersama mereka (M.Ali Chanafiah, 2003: 35).

9 Benteng peninggalan Inggris yang pernah menduduki Bengkulu sejak tahun 1685 - 1825.

10 Menurut cerita Burhan, keesokan harinya Bung Karno menyuruh Boerhan Wahid untuk mengambil sepedanya.

11 Bung Karno menolak sesuatu hukum agama yang tidak nyata berdasarkan perintah oleh Allah dan Rasulnya (Ramadhan K.H, 2011:317)

12 (Bijlage : Afschrift : Een beeld van de maandelijksche uitgaven voor de huishouding van Ir. Soekarno geinterneerde te Benkoelen, Binnenlandsch Bestuur, ANRI, 2076). 
${ }^{13}$ Satu orang Sunda namanya Muin, dan satu lagi orang daerah Lebong namanya Padil (Ramadhan KH, 2007: 322).

14 Salmiah akhirnya membeli satu meja hias dan buffet yang juga hasil rancangan Bung Karno (M.Ali Chanafiah, 2003:56).

15 Bung Karno juga mengusulkan agar para pengajar berusaha untuk menanamkan rasa cinta tanah air dan bangsa, dan agama. 